\title{
Bone Accumulations of Spotted Hyaenas (Crocuta crocuta, Erxleben, 1777) as Indicators of Diet and Human Conflict; Mashatu, Botswana
}

\author{
Brian F. Kuhn \\ Institute for Human Evolution, School of Geosciences, University of the Witwatersrand (WITS), Johannesburg 2050, South Africa \\ Correspondence should be addressed to Brian F. Kuhn, kuhnbf@gmail.com
}

Received 18 November 2011; Revised 2 March 2012; Accepted 2 March 2012

Academic Editor: Bruce Leopold

Copyright () 2012 Brian F. Kuhn. This is an open access article distributed under the Creative Commons Attribution License, which permits unrestricted use, distribution, and reproduction in any medium, provided the original work is properly cited.

\begin{abstract}
In a region where free ranging domestic species mix with wildlife, it is imperative to determine what, if any, predation may have occurred on domestic stock. As human settlements continuously encroach upon wild habitats, determining the types of predatorhuman conflicts that exist can be crucial to conserve numerous predator species. The partial diet of spotted hyaenas (Crocuta crocuta) of the Mashatu Game Reserve, Botswana, was established via analyses of faunal remains associated with four dens to determine predation/scavenging on wild or domestic species. Domestic species composed less than $3 \%$ of identified faunal remains. We acknowledge that this methodology is biased against small mammals, but, when combined with sociological studies, this methodology will aid in determining alleged predation on domestic stock by spotted hyaenas. Results indicated that the spotted hyaenas in question feed primarily on wild species.
\end{abstract}

\section{Introduction}

Spotted hyaenas (Crocuta crocuta) have long been the source for studies on feeding behaviour [1-12]. Once thought to be primarily a scavenger, more recent studies have shown spotted hyaenas to be consummate hunters, killing up to $95 \%$ of the animals consumed [11], and preferring the most abundant prey at a site weighing between 56 and $182 \mathrm{~kg}$ [13]. Having a reputation for killing domestic stock [14] but also thought to adjust behavioural patterns to avoid human presence $[15,16]$, it was uncertain if the resident spotted hyaenas of the Mashatu Game Reserve, Tuli Block, Botswana, were feeding (via predation or scavenging) on domestic animal populations. Reports from the Botswana government do not list hyaenas (they do not appear to differentiate between spotted hyaenas or brown hyaenas (Parahyaena brunnea, Thunberg, 1820) in the top five species of problem animals countrywide when it comes to conflicts with humans, but they are listed as potential problem animals. In the Central District (where the Tuli Block is located), hyaenas in general rank fourth, after lion (Panthera leo, Linnaeus, 1758), leopard (Panthera pardus, Linnaeus, 1758), and elephant (Loxodonta africana, Blumenbach, 1797), amongst problem animals [17]. A study in East Africa has shown that lions have a much greater effect on livestock populations than spotted hyaenas, but the local pastoralists have a greater animosity towards hyaenas [18]. In contrast, a survey in Ethiopia indicated that spotted hyaenas are responsible for direct predation on domestic stock [19]. For the most part, studies determining which species has the most detrimental effect on livestock are conducted using scat analyses of said carnivore species and/or interviewing the local population and relying on their identifications and interpretations. It must also be acknowledged until recently that the Botswana government policy was to pay out for livestock killed by lions but not for livestock killed by hyaenas (L. Frank Pers Comm. 2011), which may have influenced the populations' identifications of conflict species.

In addition to the multitude of behavioural and ecological studies on spotted hyaenas, specific taphonomic studies involving extant spotted hyaenas have also been conducted to better understand their role in fossil deposits [20-31]. The taphonomic implications of this study have been previously published $[28,30,31]$; the same data and methodologies 


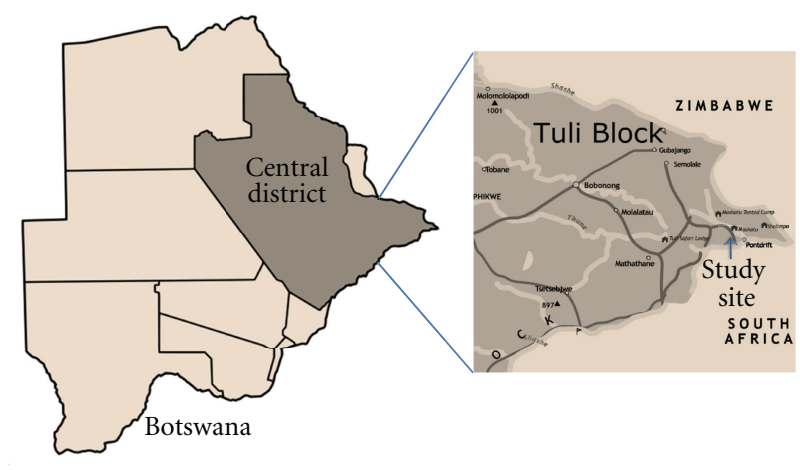

Figure 1: Map showing Botswana's Central District, the Tuli Block and study area.

are used to examine patterns of predation/scavenging as documented by skeletal accumulations at den sites. These methodologies, specifically the examination and identification to prey species, of faunal remains accumulated at hyaena dens. Here we demonstrate how methodologies used in taphonomic studies can be implemented in modern humananimal conflict issues to help gauge the amount of predation spotted hyaenas may inflict on domestic stock.

In Botswana, total livestock units (LUs) combining wild and domestic species in 2003 were $4.39 \mathrm{LU} / \mathrm{Km}^{2}$. Domestic species composed $79 \%$ of the total LU biomass (the remaining 21\% consisting of wildlife). The Central District, the largest district covering $147,730 \mathrm{~km}^{2}$, of which the Tuli Block makes up a very small portion, 300,000 hectares, reported $55.3 \%$ of nation-wide problem-animal incidents. Three hundred twenty one of these incidents involved hyaena compared to lions involved in 1,857-recorded incidents [17]. Results indicated that, despite a high number of domestic species available, the spotted hyaenas of the Mashatu Game Reserve appear to be surviving primarily by feeding on wild species.

\section{Study Site}

The Mashatu Game Reserve lies in the eastern portion of the Central District of Botswana in a region known as the Tuli Block. The Tuli Block lies on the eastern central border region of Botswana, bordered by Zimbabwe to the north and northeast and South Africa to the south and southeast (Figure 1). Unfenced, the reserve covers approximately 30,000 ha of semi arid Bushvelt receiving approximately $177 \mathrm{~mm}$ of rainfall per annum (Mashatu.com 2006). The reserve supports numerous species including large herds of elephants (Loxodonta africana, Blumenbach, 1797), kudu (Tragelaphus strepsiceros, Pallas, 1766), wildebeest (Connochaetes taurinus, Burchell, 1823), zebra (Equus quagga, Boddaert, 1785), and impala (Aepyceros melampus, Lichtenstein, 1812). In addition to the wide variety of herbivores the area also supports numerous carnivore species such as the aforementioned spotted hyaenas and lions, leopards, caracals (Caracal caracal, Schreber, 1776), black-backed jackals (Canis mesomelas, Schreber, 1775), and wild dogs (Lycaon pictus, Temminck, 1820). The region has a diverse fauna (Table 1 ). While the region is well within the natural range of brown hyaenas, there has only been a single confirmed sighting of brown hyaena in the past decade (J. Selier pers. com.). This, combined with observed occurrences of only spotted hyaenas associated with the four dens, enables us to conclude that spotted hyaenas primarily use the dens. All four dens collected from were caves, three of which were located at the base of the escarpment, and the fourth den/cave located just below the top edge of the escarpment. Den 2 had juvenile and adult hyaenas present prior to the study beginning and Den 4 had both adult and juvenile hyaenas present during the study. It has been shown that hyaenas collect bones in greater numbers when young are present thus, we infer that all four dens were used as maternity dens at some point in the recent past [2-4, 6$8,24,27,31]$. The condition of the bones collected suggested a time frame of a few months to over six years since the material was deposited at the dens.

The human population of the Tuli Block was recently estimated at 7,954 people [32] and domestic livestock units at approximately $3.4 \mathrm{LU} / \mathrm{Km}^{2}$ [17]. The present study was based out of the Kgotla camp in the southwest part of the reserve and concentrated on regions adjacent to the Motloutse River and Motloutse archaeology site.

The human populations on the fringes of the reserve are surviving via the farming of livestock. Thus, even though the local populations take care with their livestock by the use of kraals and dogs, livestock is still available for the local carnivores to prey on. During the day it was common to see livestock roaming in the study area. While the hyaenas living deeper inside of the reserves would likely have less contact with domestic species, the clans living in the study area would have greater access to livestock.

\section{Materials and Methods}

In addition to long-term general observations made by staff of the reserve, which identified three dens, our study was conducted over three months (October-December of 2004). During this time dens of spotted hyaenas were identified and observed. Additional dens were located via random searches consisting of hikes up to 20 kilometres, all starting from the Motloutse archaeology site and radiating outward. No two searches covered the same area, and none could maintain a straight line due to the terrain. Most searches formed circular patterns skirting the base of the escarpments or covering the tops of said escarpments where spotted hyaenas were known to frequent. At the end of the study period faunal remains from four of the eight identified dens were collected and transported to lab facilities at the University of the Witwatersrand, Johannesburg, South Africa. The dens collected were chosen purely for logistical reasons as they were within 5-7 kilometres from where I was required to leave my vehicle. Specimens were identified to skeletal element and species or class size where possible, using reference collections housed at the Institute for Human Evolution and the Bernard Price Institute, University of the Witwatersrand. In addition bone identification manuals by Schmid [33], Walker [34], and Hillson [35] were used to 
TABLE 1: Mammal species living in Mashatu and surrounds.

\begin{tabular}{|c|c|c|}
\hline & Common name & Latin name \\
\hline \multirow[t]{3}{*}{ Bovid class 1} & Klipspringer & Oreotragus oreotragus \\
\hline & Steenbok & Raphicerus campestris \\
\hline & Common duiker & Sylvicapra grimmia \\
\hline \multirow[t]{3}{*}{ Bovid class 2} & Bushbuck & Tragelaphus scriptus \\
\hline & Impala & Aepyceros melampus \\
\hline & Goat (domestic) & Capra hircus \\
\hline \multirow[t]{4}{*}{ Bovid class 3} & Kudu & Tragelaphus strepsiceros \\
\hline & Waterbuck & Kobus ellipsiprymnus \\
\hline & Blue wildebeest & Connochaetes taurinus \\
\hline & Cow (domestic) & Bos sp. \\
\hline Bovid cslass 4 & Eland & Taurotragus oryx \\
\hline \multirow[t]{2}{*}{ Equid } & Burchell's zebra & Equus quagga \\
\hline & Donkey (domestic) & Equus asinus \\
\hline \multirow[t]{3}{*}{ Primate } & Chacma Baboon & Papio cynocephalus ursinus \\
\hline & Vervet monkey & Cercopithecus aethiops \\
\hline & Thick-tailed bushbaby & Galago crassicaudatus \\
\hline \multirow[t]{22}{*}{ Carnivore } & Lion & Panthera leo \\
\hline & Leopard & Panthera pardus \\
\hline & Cheetah & Acinonyx jubatus \\
\hline & Caracal & Caracal caracal \\
\hline & Serval & Leptailurus serval \\
\hline & African wild cat & Felis silvestris \\
\hline & Bat-eared fox & Otocyon megalotis \\
\hline & Black-backed jackal & Canis mesomelas \\
\hline & Cape fox & Vulpes chama \\
\hline & Aardwolf & Proteles cristatus \\
\hline & Spotted hyaena & Crocuta crocuta \\
\hline & Brown hyaena & Parahyaena brunnea \\
\hline & Cape clawless otter & Aonyx capensis \\
\hline & Honey badger & Mellivora capensis \\
\hline & Striped polecat & Ictonyx striatus \\
\hline & African civet & Civettictis civetta \\
\hline & Large-spotted genet & Genetta tigrina \\
\hline & Small-spotted genet & Genetta genetta \\
\hline & Banded mongoose & Mungos mungo \\
\hline & Selous mongoose & Paracynictis selousi \\
\hline & Slender mongoose & Galerella sanguinea \\
\hline & White-tailed mongoose & Ichneumia albicauda \\
\hline \multirow[t]{2}{*}{ Suid } & Bushpig & Potamochoerus larvatus \\
\hline & Warthog & Phacochoerus africanus \\
\hline \multirow[t]{2}{*}{ Rodent } & Porcupine & Hystrix africaeaustralis \\
\hline & Springhare & Pedetes capensis \\
\hline \multirow[t]{2}{*}{ Hyrax } & Rock dassie & Procavia capensis \\
\hline & Yellow-spotted dassie & Heterohyrax brucei \\
\hline \multirow[t]{6}{*}{ Other } & Hippopotamus & Hippopotamus amphibius \\
\hline & Giraffe & Giraffa camelopardalis \\
\hline & Elephant & Loxodonta africana \\
\hline & Aardvark & Orycteropus afer \\
\hline & Scrub hare & Lepus saxatilis \\
\hline & Pangolin & Manis temminckii \\
\hline
\end{tabular}




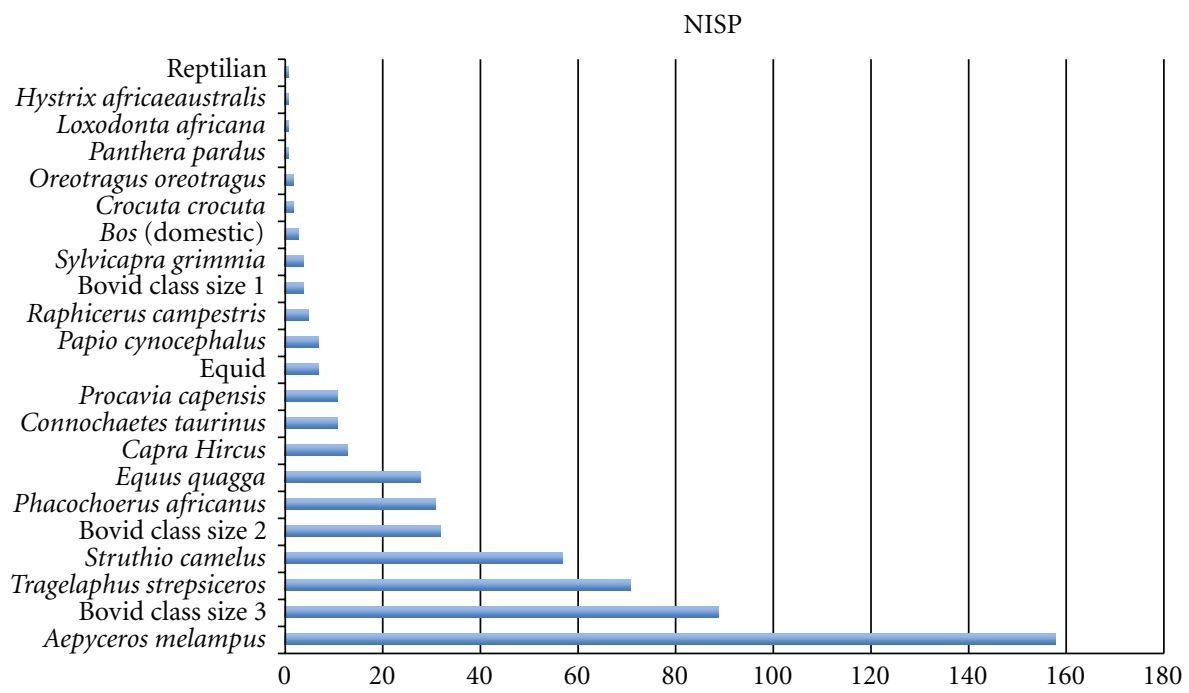

Figure 2: Abundance of identified species by NISP (Number of Identified Specimens).

TABLE 2: Identified species or class size, with (number of identified specimens) (NISP), (minimum number of individuals) (MNI) and which dens they were found. Bovid class size based on kilograms and follows Brain [36].

\begin{tabular}{|c|c|c|c|}
\hline Species & NISP & MNI & Dens \\
\hline $\begin{array}{l}\text { Aepyceros } \\
\text { melampus }\end{array}$ & 158 & 13 & $1,2,3,4$ \\
\hline Bovid class size 3 & 89 & 5 & $1,2,3,4$ \\
\hline $\begin{array}{l}\text { Tragelaphus } \\
\text { strepsiceros }\end{array}$ & 71 & 4 & $1,3,4$ \\
\hline Struthio camelus & 57 & 4 & 4 \\
\hline Bovid class size 2 & 32 & 2 & $1,2,3,4$ \\
\hline $\begin{array}{l}\text { Phacochoerus } \\
\text { africanus }\end{array}$ & 31 & 2 & $2,3,4$ \\
\hline Equus quagga & 28 & 4 & $1,2,3,4$ \\
\hline Capra hircus & 13 & 5 & 4 \\
\hline $\begin{array}{l}\text { Connochaetes } \\
\text { taurinus }\end{array}$ & 11 & 3 & $2,3,4$ \\
\hline Procavia capensis & 11 & 2 & $1,2,3,4$ \\
\hline Equid & 7 & 2 & 3 \\
\hline Papio cynocephalus & 7 & 2 & $2,3,4$ \\
\hline $\begin{array}{l}\text { Raphicerus } \\
\text { campestris }\end{array}$ & 5 & 2 & 4 \\
\hline Bovid class size 1 & 4 & 1 & 1,4 \\
\hline Sylvicapra grimmia & 4 & 2 & 1,4 \\
\hline Bos (domestic) & 3 & 1 & 4 \\
\hline Crocuta crocuta & 2 & 1 & 2 \\
\hline $\begin{array}{l}\text { Oreotragus } \\
\text { oreotragus }\end{array}$ & 2 & 1 & 4 \\
\hline Panthera pardus & 1 & 1 & 4 \\
\hline Loxodonta africana & 1 & 1 & 3 \\
\hline $\begin{array}{l}\text { Hystrix } \\
\text { africaeaustralis }\end{array}$ & 1 & 1 & 4 \\
\hline Reptilian & 1 & 1 & 1 \\
\hline Total & 539 & 60 & \\
\hline
\end{tabular}

aid in the identification of the collected remains. From this the number of identified specimens (NISP) and minimum number of individuals (MNI) for each den was calculated. All specimens are currently stored at the Palaeosciences Centre, University of the Witwatersrand, Johannesburg, South Africa. Bovid size classes are based on weight and follow Brain [36].

\section{Results}

We collected 976 specimens of faunal remains from four dens. Of this total, $69.4 \%$ of the specimens were identified to skeletal element and $55.2 \%$ to species or class size (Table 2, Figure 2). Examination of the faunal remains collected at the den sites indicated that impala (Aepyceros melampus) was the most common prey species and consisted of $29.3 \%$ of the identified remains. The second most common prey item identified was that of unknown bovid class size 3 (16.5\%), followed by kudu (Tragelaphus strepsiceros) (13.2\%) and ostrich (Struthio camelus, Linnaeus, 1758) (10.6\%). The remaining identified species composed less than $10 \%$ (per species) of identified remains. Combined domestic species identified as cow (Bos sp.) and goat (Capra hircus, Linnaeus, 1758) composed less than $3 \%$ of the total identified remains.

Breakdown of skeletal elements is shown for taxonomically identified family groups, domestic groups, and class size in Table 3. Bovids of class size 2 and 3 show a much greater variety in skeletal elements, with class 2 having at least two samples of each skeletal element listed in Table 3. Domestic Bos yielded only three elements, while domestic Capra had 12 total identified elements, eight of which were mandibles. Carnivores were the group with the least number of elements, two.

\section{Discussion}

Considering numbers of domestic species available (79\% of the total livestock unit (LU) biomass), results indicate that the spotted hyaenas in the study region are consuming primarily wild species that inhabit the region. Unknown 
TABle 3: Number of select skeletal elements identified for the domestic species, wild bovid class size 1, 2, and 3 [36], equid, carnivore, suid, and primate.

\begin{tabular}{|c|c|c|c|c|c|c|c|c|c|}
\hline & Domestic bos & Domestic Caprid & Wild class 1 & Wild class 2 & Wild class 3 & Equid & Carnivore & Suid & Primate \\
\hline Skull & 0 & 0 & 2 & 3 & 3 & 0 & 1 & 3 & 0 \\
\hline Maxilla & 0 & 0 & 0 & 2 & 0 & 0 & 0 & 0 & 1 \\
\hline Mandible & 0 & 8 & 0 & 5 & 1 & 1 & 0 & 6 & 0 \\
\hline Pelvic & 0 & 0 & 1 & 6 & 3 & 3 & 0 & 0 & 0 \\
\hline Scapula & 0 & 1 & 0 & 8 & 8 & 1 & 0 & 0 & 0 \\
\hline Humerus & 1 & 1 & 1 & 20 & 17 & 5 & 0 & 0 & 1 \\
\hline Radius & 0 & 0 & 2 & 12 & 8 & 3 & 0 & 2 & 0 \\
\hline Ulna & 0 & 0 & 1 & 5 & 6 & 0 & 1 & 0 & 0 \\
\hline Metacarpal & 1 & 0 & 0 & 11 & 7 & 7 & 0 & 2 & 0 \\
\hline Femur & 0 & 0 & 2 & 19 & 7 & 3 & 0 & 1 & 2 \\
\hline Tibia & 0 & 0 & 2 & 15 & 11 & 4 & 0 & 2 & 0 \\
\hline Calcaneus & 0 & 1 & 0 & 4 & 4 & 0 & 0 & 0 & 0 \\
\hline Astragalus & 0 & 0 & 0 & 2 & 5 & 0 & 0 & 0 & 0 \\
\hline Metatarsal & 1 & 0 & 0 & 8 & 8 & 1 & 0 & 1 & 1 \\
\hline Phalanx 1 & 1 & 1 & 1 & 20 & 7 & 5 & 0 & 0 & 0 \\
\hline Phalanx 2 & 0 & 0 & 0 & 11 & 4 & 2 & 0 & 0 & 0 \\
\hline Phalanx 3 & 0 & 0 & 0 & 7 & 2 & 1 & 0 & 0 & 0 \\
\hline Total bones & 4 & 12 & 12 & 158 & 101 & 36 & 2 & 17 & 5 \\
\hline
\end{tabular}

bovid class 2 (which may include domestic goats and wild bovids, such as impala) and bovid class 3 (which could have domestic cattle and wild bovids) combined compose $22.5 \%$ of the identified assemblage. While it is acknowledged that some of this $22.5 \%$ may include domestic goat or cattle, it is argued here that the ratios of bovid species represented in the unidentifiable remains would likely follow the ratios of identified remains. Thus, the most unknown bovid class 2 would most likely be comprised of impala, and the bulk of unknown bovid class 3 kudu. Of note is that in addition to impala, only zebra (Equus quagga), hyrax, and unknown bovids of class sizes 2 and 3 are present in all four dens. This observation is suggestive that these prey types are in all probability the preferred prey of resident spotted hyaenas.

Examination of the identified skeletal elements indicates that bovid class sizes 2 and 3 (both identified to species as well as those identified only to class size) along with equids (zebra) show the greatest variation of identified elements. Unlike carnivores, domestic species and primates provided relatively few skeletal elements to the hyaena den assemblages. The bovids and equids illustrate that most body parts are being collected at the den sites. The difference between identified skeletal remains of the wild bovids and equids compared to the warthogs, domestic species, carnivores, and primates may very well be indicative of the difference between hunted prey and prey which has been scavenged. In particular the wild class 2 and class 3 bovids that have all major skeletal elements represented in the assemblages, which may infer predation. However, the reduced number of skeletal elements from domestic Bos, Caprid, carnivore, suid, and primate would suggest scavenging from human settlements or other predator kills.

This study concurs with reports published by the Botswana government [17] in that spotted hyaenas, while potentially a problem species as evidenced by a low percentage of identified domestic remains at den sites are not a major contributor to predation upon livestock in the Tuli Block. It must also be acknowledged that the remains studied here may or may not have come solely from hyaenid predation but could have been scavenged from the kills of leopard and or lion. Additionally, it must be emphasised that presence of so few domestic remains in the dens suggests that these particular elements were likely scavenged from human settlements.

Whether or not these results are typical of spotted hyaenas across their range is unknown. This study was conducted in a small area on the edge of the reserve. While this area was chosen for known hyaena activity within close proximity to human populations, it cannot be said whether these particular hyaenas are behaving the same as hyaenas from other regions. What has been demonstrated is a methodology from which hyaena-human conflict can be explored beyond and in addition to the previous use of interviewing the local populations. While there will always be conflict between wildlife and humans, especially when it comes to depredation of domestic stock, through bone-based ecological research and education, we should be able to reduce the unwarranted animosity many rural populations have towards spotted hyaenas. This study takes a critical, initial step to demonstrate that spotted hyaenas in the study area are not directly preying on large numbers of domestic stock. In addition we have illustrated another way in which to determine whether or not hyaenas in a given region are indeed problem animals or not.

\section{Acknowledgments}

This work was supported by the University of Pretoria and the Palaeontological Scientific Trust (PAST). Grateful appreciation goes to The Mashatu Game Reserve, especially Pete Le Roux, Jeanetta Selier, and Paul Grobler. Also the 
author is grateful to Ryan Franklin, Joost Segera, Michiel van Silfhout, and Jess Kuhn for aiding in collecting faunal remains. Additional appreciation to Bruce Leopold and six anonymous reviewers whose comments on earlier versions of this manuscript were most helpful.

\section{References}

[1] A. J. Sutcliffe, "Spotted hyaena: crusher, gnawer, digester and collector of bones," Nature, vol. 227, no. 5263, pp. 1110-1113, 1970.

[2] H. Kruuk, The Spotted Hyena: A Study of Predation and Social Behavior, University of Chicago Press, Chicago, Ill, USA, 1972.

[3] S. K. Bearder, "Feeding habits of spotted hyaenas in a woodland habitat," East African Wildlife Journal, vol. 15, pp. 163-290, 1977.

[4] J. R. Henschel, R. Tilson, and F. von Blottnitz, "Implications of a spotted hyaena bone assemblage in the Namib Desert," South African Archaeological Bulletin, vol. 3, pp. 127-131, 1979.

[5] J. D. Skinner and R. J. van Aarde, "The distribution and ecology of the brown hyaena Hyaena brunnea and spotted hyaena Crocuta crocuta in the central Namib Desert," Madoqua, vol. 12, no. 4, pp. 231-239, 1981.

[6] R. L. Tilson and W. J. Hamilton, "Social dominance and feeding patterns of spotted hyaenas," Animal Behaviour, vol. 32, no. 3, pp. 715-724, 1984.

[7] J. R. Henschel and J. D. Skinner, "The diet of the spotted hyaenas Crocuta crocuta in Kruger National Park," African Journal of Ecology, vol. 28, no. 1, pp. 69-82, 1990.

[8] M. G. L. Mills, Kalahari Hyaenas: The Comparative Ecology of Two Species, Unwin-Hyman, London, UK, 1990.

[9] S. M. Cooper, "The hunting behaviour of spotted hyaenas (Crocuta crocuta) in a region containing both sedentary and migratory populations of herbivores," African Journal of Ecology, vol. 28, no. 2, pp. 131-141, 1990.

[10] K. E. Holekamp, L. Smale, R. Berg, and S. M. Cooper, "Hunting rates and hunting success in the spotted hyena (Crocuta crocuta)," Journal of Zoology, vol. 242, no. 1, pp. 1-15, 1997.

[11] S. M. Cooper, K. E. Holekamp, and L. Smale, "A seasonal feast: long-term analysis of feeding behaviour in the spotted hyaena (Crocuta crocuta)," African Journal of Ecology, vol. 37, no. 2, pp. 149-160, 1999.

[12] K. E. Holekamp, S. T. Sakai, and B. L. Lundrigan, "The spotted hyena (Crocuta crocuta) as a model system for study of the evolution of intelligence," Journal of Mammalogy, vol. 88, no. 3, pp. 545-554, 2007.

[13] M. W. Hayward, "Prey preferences of the spotted hyaena (Crocuta crocuta) and degree of dietary overlap with the lion (Panthera leo)," Journal of Zoology, vol. 270, no. 4, pp. 606-614, 2006.

[14] IUCN-Hyaena specialist group, 2009, http://www.hyaenidae .org/the-hyaenidae/spotted-hyena-crocuta-crocuta/crocutadiet-and-foraging.html.

[15] E. E. Boydston, K. M. Kapheim, H. E. Watts, M. Szykman, and K. E. Holekamp, "Altered behaviour in spotted hyenas associated with increased human activity," Animal Conservation, vol. 6, no. 3, pp. 207-219, 2003.

[16] J. M. Kolowski and K. E. Holekamp, "Ecological and anthropogenic influences on space use by spotted hyaenas," Journal of Zoology, vol. 277, no. 1, pp. 23-36, 2009.

[17] Wildlife Statistics, Central Statistics Office, Gabarone, Botswana, 2004.
[18] L. G. Frank, "Spotted hyenas and livestock in Laikipia, Kenya," Hyaena Specialist Group Newsletter, vol. 7, pp. 12-17, 2000.

[19] G. Yirga and H. Bauer, "Livestock depredation of the spotted hyena (Crocuta crocuta) in Southern Tigray, Northern Ethiopia," International Journal of Ecology and Environmental Sciences, vol. 36, no. 1, pp. 67-73, 2010.

[20] L. R. Binford, M. G. L. Mills, and N. M. Stone, "Hyena scavenging behavior and its implications for the interpretation of faunal assemblages from FLK 22 (the Zinj floor) at olduvai gorge," Journal of Anthropological Archaeology, vol. 7, no. 2, pp. 99-135, 1988.

[21] K. Cruz-Uribe, "Distinguishing hyaena from hominid bone accumulations," Journal of Field Archaeology, vol. 18, pp. 467486, 1991.

[22] Y. M. Lam, "Variability in the behaviour of spotted hyaenas as taphonomic agents," Journal of Archaeological Science, vol. 19, no. 4, pp. 389-406, 1992.

[23] T. R. Pickering, "Reconsideration of criteria for differentiating faunal assemblages accumulated by hyenas and hominids," International Journal of Osteoarchaeology, vol. 12, no. 2, pp. 127-141, 2002.

[24] J. D. Skinner, "Bone collecting by hyaenas: a review," Transactions of the Royal Society of South Africa, vol. 61, no. 1, pp. 4-7, 2006.

[25] J. T. Faith, "Sources of variation in carnivore tooth-mark frequencies in a modern spotted hyena (Crocuta crocuta) den assemblage, Amboseli Park, Kenya," Journal of Archaeological Science, vol. 34, no. 10, pp. 1601-1609, 2007.

[26] J. T. Faith, C. W. Marean, and A. K. Behrensmeyer, "Carnivore competition, bone destruction, and bone density," Journal of Archaeological Science, vol. 34, no. 12, pp. 2025-2034, 2007.

[27] J. T. Pokines and J. C. Kerbis Peterhans, "Spotted hyena (Crocuta crocuta) den use and taphonomy in the Masai Mara National Reserve, Kenya," Journal of Archaeological Science, vol. 34, no. 11, pp. 1914-1931, 2007.

[28] B. F. Kuhn, L. R. Berger, and J. D. Skinner, "Variation in tooth mark frequencies on long bones from the assemblages of all three extant bone-collecting hyaenids," Journal of Archaeological Science, vol. 36, no. 2, pp. 297-307, 2009.

[29] S. W. Lansing, S. M. Cooper, E. E. Boydston, and K. E. Holekamp, "Taphonomic and zooarchaeological implications of spotted hyena (Crocuta crocuta) bone accumulations in kenya: a modern behavioral ecological approach," Paleobiology, vol. 35, no. 2, pp. 289-309, 2009.

[30] B. F. Kuhn, L. R. Berger, and J. D. Skinner, "Examining criteria for identifying and differentiating fossil faunal assemblages accumulated by hyenas and hominins using extant hyenid accumulations," International Journal of Osteoarchaeology, vol. 20, no. 1, pp. 15-35, 2010.

[31] B. F. Kuhn, Hyaenids: Taphonomy and Implications for the Palaeoenvironment, Cambridge Scholars Publishing, London, UK, 2011.

[32] 2011, http://www.traveljournals.net/explore/botswana/map/ m2006523/tuli_block.html.

[33] E. Schmid, Atlas of Animal Bones, Elsevier, Amsterdam, The Netherlands, 1972.

[34] R. Walker, A Guide to Post-Cranial Bones of East African Animals: Mrs Walker's Bone Book, Hylochoerus Press, Norwich, UK, 1985.

[35] S. Hillson, Mammal Bones and Teeth: An Introductory Guide to Methods of Identification, Dorset Press, Dorchester, UK, 1992.

[36] C. K. Brain, The Hunters or the Hunted? An Introduction to African Cave Taphonomy, The University of Chicago Press, Chicago, Ill, USA, 1981. 

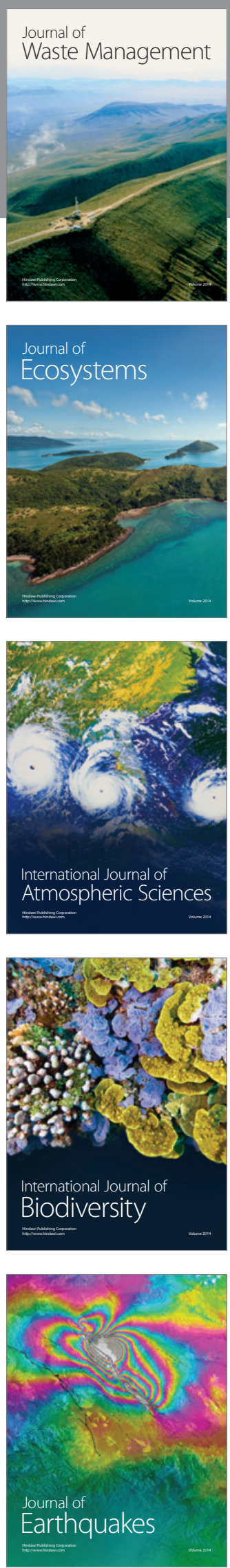
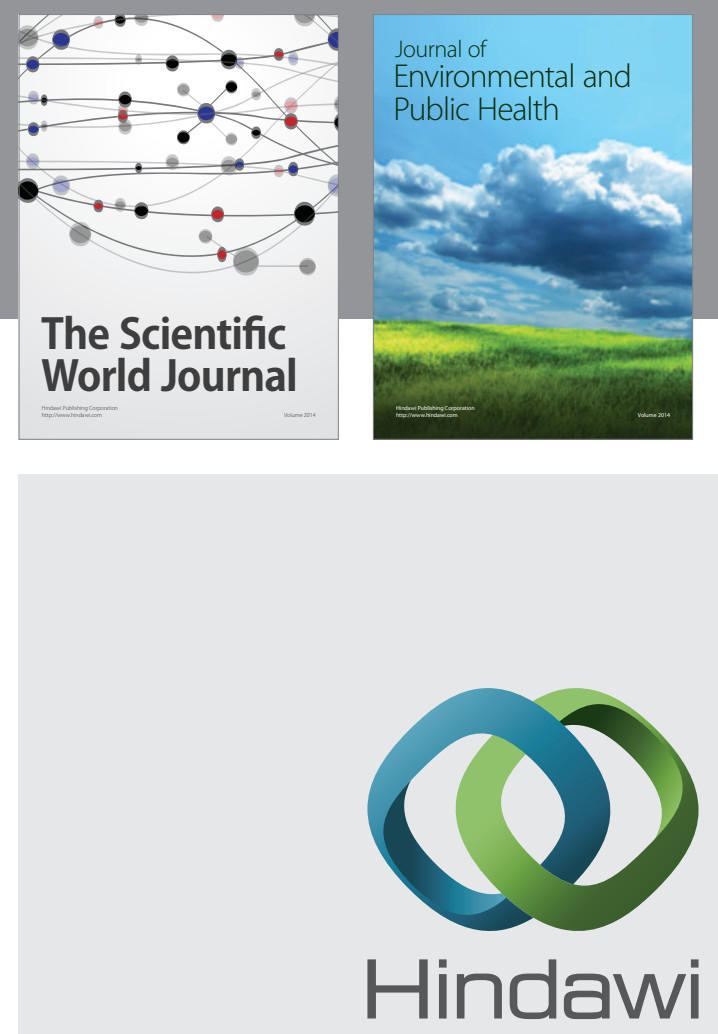

Submit your manuscripts at

http://www.hindawi.com
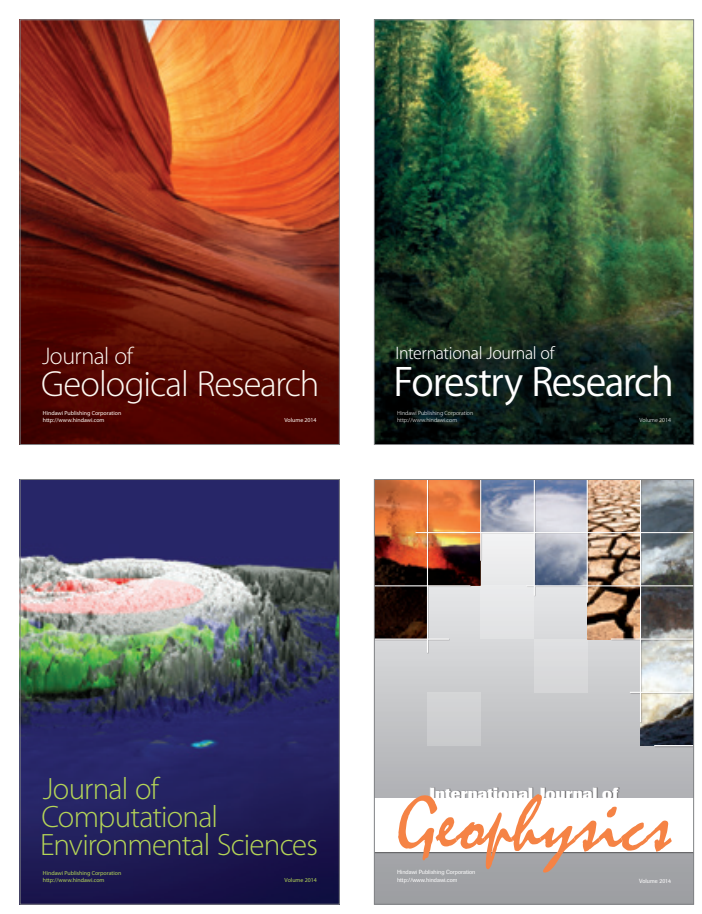
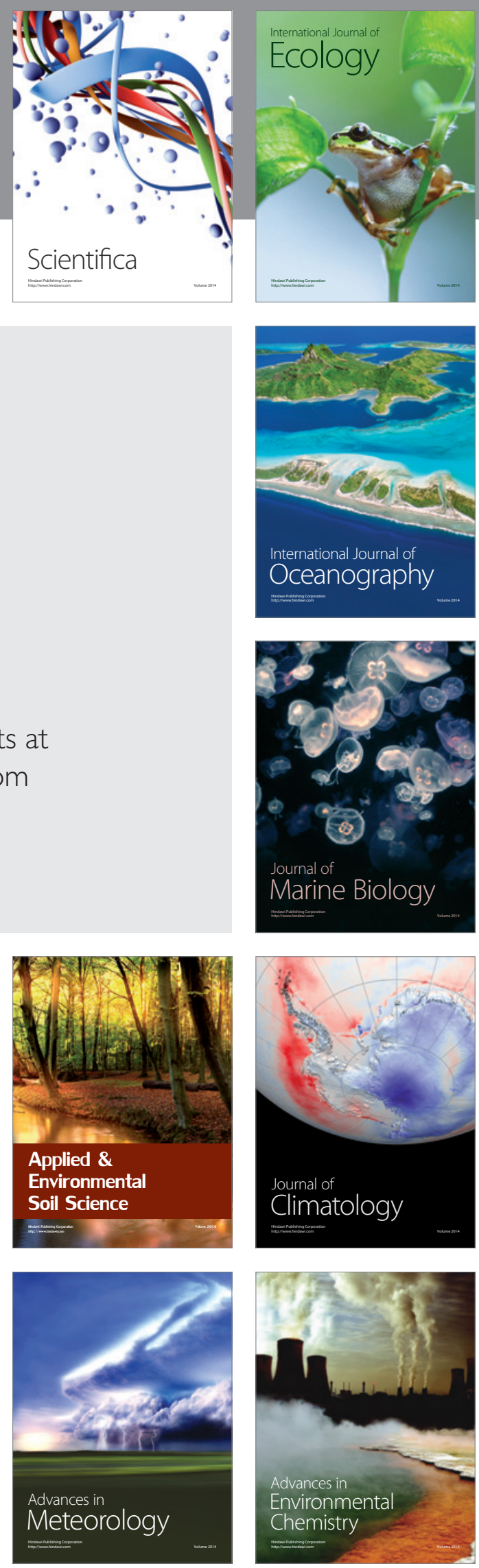